Article

\title{
Evaluation of Yeast Strains for Pomegranate Alcoholic Beverage Production: Effect on Physicochemical Characteristics, Antioxidant Activity, and Aroma Compounds
}

\author{
Evangelos Kokkinomagoulos ${ }^{1}$ (D), Anastasios Nikolaou ${ }^{2}$ (D), \\ Yiannis Kourkoutas ${ }^{2}$ and Panagiotis Kandylis ${ }^{1, *(D)}$ \\ 1 Laboratory of Oenology and Alcoholic Beverages, Department of Food Science and Technology, \\ School of Agriculture, Aristotle University of Thessaloniki, P.O. Box 235, 54124 Thessaloniki, Greece; \\ ekokkinom@gmail.com \\ 2 Laboratory of Applied Microbiology \& Biotechnology, Department of Molecular Biology \& Genetics, \\ Democritus University of Thrace, GR-68100 Alexandroupolis, Greece; anikol@mbg.duth.gr (A.N.); \\ ikourkou@mbg.duth.gr (Y.K.) \\ * Correspondence: pkandylis@agro.auth.gr or pkandylis@yahoo.gr; Tel.: +30-2310-991-678
}

Received: 14 September 2020; Accepted: 13 October 2020; Published: 14 October 2020

\begin{abstract}
In the present study, three commercial yeasts (for wine, beer, and cider) were evaluated for the production of pomegranate alcoholic beverage (PAB) from a juice of Wonderful variety. The physicochemical characteristics, antioxidant activity, and aromatic profiles of PABs were investigated before and after fermentation, while the effect of yeast strain and fermentation temperature $\left(15\right.$ and $25^{\circ} \mathrm{C}$ ) was also evaluated. The PABs contained ethanol in the ranges of $5.6-7.0 \% \mathrm{v} / \mathrm{v}$, in combination with glycerol (2.65-6.05 g L $\left.{ }^{-1}\right)$, and low volatile acidity. Total flavonoid content, total phenolic content, free radical-scavenging activity, and total monomeric anthocyanin content appeared to decrease after fermentation, possibly due to hydrolysis, oxidation, and other reactions. In general, PABs retained $81-91 \%$ of free radical-scavenging activity, $29-41 \%$ of phenolics, $24-55 \%$ of flavonoids, and $66-75 \%$ of anthocyanins. The use of different yeast affected mainly flavonoids and anthocyanins, and yeast strain M02 resulted in the highest values after fermentation. In PABs, 30 different volatile compounds were identified, specifically 15 esters, 4 organic acids, 8 alcohols, and 3 terpenes. The principal component analysis showed that the fermentation temperature affected significantly volatile composition, whereas, among the yeasts, WB06 is the one that seems to differentiate. The findings of this study show that the selection of the appropriate yeast and fermentation temperature is very crucial and affects the characteristics of the final product.
\end{abstract}

Keywords: pomegranate; alcoholic fermentation; antioxidants; phenolic compounds; volatile profile; GC/MS; flavonoid; Punica granatum L.

\section{Introduction}

Pomegranate (Punica granatum L.) is a fruit that has aroused scientific interest for decades, due to the numerous beneficial effects that it can possess as food, its pharmacological and toxicological properties, such as antioxidant, antimicrobial, anti-inflammatory, and anticarcinogenic, and numerous applications in several food products [1]. Pomegranate is a well-known source of valuable nutrients, whereas the production and consumption are showing continuously increasing trends worldwide, a fact that can be probably related with the increase of consumers' awareness regarding the possible health benefits of pomegranate consumption, through the development of science and technology. 
Additionally, pomegranate consumption is not restricted only to fresh fruit, but it also exists in the market as another alternative product, as pomegranate wine or pomegranate alcoholic beverage (PAB), a product of alcoholic fermentation.

It is known that fruit processing (e.g., pasteurization) can lead to a reduction of fresh fruit aromatic intensity, which in the case of pomegranate, is already low. Consequently, these processes can influence consumer acceptance. The fact that pomegranates generally possess low aromatic intensities means that the isolation and identification of volatile aromatic compounds have been difficult, whereas different studies suggest different results regarding the aromatic profile of pomegranate and its products. According to the literature, hexanal, limonene, trans-2-hexanal, cis-2-hexanal, and a-terpineol are the major aromatic compounds of fresh pomegranate fruit [2], while 3-methyl butanal, ethyl butanoate, isopentyl acetate, hexanol, diethyl allyl malonate, and $\alpha$-ionone in the case of pomegranate juice [3]. Studies regarding the aroma of PABs are limited, and they reported ethyl octanoate, ethyl decanoate, ethanol, 3-methyl-1-butanol, phenylethyl alcohol, and 3-methyl-1-butanol acetate, as main flavor compounds [4].

Since PAB is a fermentation product, its main organoleptic characteristics are affected to a large extent by fermentation and especially by the microorganisms used, as was also proved in several fermented beverages made from red dragon fruit [5], diluted honey [6], Pilsner wort [7], apple juice [8] and grape juice [9]. Several studies reported that fermentation of pomegranate juice resulted in a completely new product with altered bioactive components, mainly due to reactions of polymerization, condensation, oxidation, hydrolysis, enzyme activity, and interactions of antioxidants with yeast cell walls [10]. Nevertheless, to the best of our knowledge, the effect of different yeasts on flavor characteristics and particular bioactive compounds in PAB has not been well investigated, and it is only limited in studies with one yeast strain $[4,11]$.

The main objectives of the present study were to investigate the physicochemical characteristics, antioxidant properties, bioactive compounds, and flavor profile of PABs fermented with three commercial yeast strains at $15^{\circ} \mathrm{C}$ and $25^{\circ} \mathrm{C}$. Total phenolic content (TPC), total flavonoid content (TFC), $\mathrm{DPPH}^{\bullet}$ free radical, main physicochemical characteristics like $\mathrm{pH}$, acidity (total and volatile), ethanol content, and reducing sugars, as well as flavor profiles were monitored before and after the fermentation process. To the best of our knowledge, this is the first time to evaluate the combined effect of yeast strain and fermentation temperature on the characteristics of PAB.

\section{Materials and Methods}

\subsection{Pomegranate Juice and Yeast Strains}

Commercial pasteurized 100\% natural pomegranate (cv. Wonderful) juice (En Karpo, Oraiokastro, Greece) was used in this study. Three commercial yeasts were employed: Craft Series SN9 Wine yeast (Saccharomyces bayanus), M02-Cider (Saccharomyces cerevisiae) (Mangrove Jack's, Albany, Auckland, New Zealand), and SAFALE ${ }^{\mathrm{TM}}$ WB-06 (Saccharomyces cerevisiae var. diastaticus) (Fermentis by Lesaffre, Marcq-en-Barœul, France).

\subsection{Fermentation of Pomegranate Juice}

Yeasts were activated prior to inoculation through rehydration in sterile distilled water and were added to $200 \mathrm{~mL}$ of pomegranate juice according to the manufacturers' directions (resulting in: M02 $3.6 \times 10^{5} \mathrm{CFU} \mathrm{mL}{ }^{-1}$, SN9 $2.5 \times 10^{5} \mathrm{CFU} \mathrm{mL}^{-1}$, and WB06 $2.4 \times 10^{7} \mathrm{CFU} \mathrm{mL}^{-1}$ ). Fermentations were carried out in sterile glass containers, with airlocks containing $70 \% \mathrm{v} / \mathrm{v}$ ethanol solution applied to them. Fermentations were carried out at $15^{\circ} \mathrm{C}$ and $25^{\circ} \mathrm{C}$. All fermentations were carried out in triplicate, and their progress was monitored by determining the weight loss as a result of $\mathrm{CO}_{2}$ production and release. The weight loss was monitored until reaching a stable weight [12]. 


\subsection{Microbiological Analysis}

After inoculation, all samples were analyzed microbiologically in order to confirm the initial inoculum. Specifically, $1 \mathrm{~mL}$ of inoculated pomegranate juice was sampled, and serial dilutions were performed in peptone water $\left(1 \mathrm{~g} \mathrm{~L}^{-1}\right.$ peptone, $8.5 \mathrm{~g} \mathrm{~L}^{-1}$ sodium chloride). Appropriate dilutions were plated on a Petri dish with YPD (Yeast extract Peptone Dextrose) agar (10 g L ${ }^{-1}$ yeast extract, $20 \mathrm{~g} \mathrm{~L}^{-1}$ peptone, $20 \mathrm{~g} \mathrm{~L}^{-1}$ glucose, $30 \mathrm{~g} \mathrm{~L}^{-1}$ bacteriological agar) and were incubated at $30{ }^{\circ} \mathrm{C}$ for $3-5$ days. Results were expressed as CFU (Colony Forming Units) $\mathrm{mL}^{-1}$.

\subsection{Determination of Reducing Sugars}

Reducing sugars (RS) were determined using the DNS (3,5-dinitrosalicylic acid) method [13], with some modifications. Specifically, in a glass test tube, $500 \mu \mathrm{L}$ of sample (appropriately diluted with distilled water) and $500 \mu \mathrm{L}$ of DNS solution $\left(10 \mathrm{~g} \mathrm{~L}^{-1}\right.$ 3,5-dinitrosalicylic acid, $300 \mathrm{~g} \mathrm{~L}^{-1}$ potassium sodium tartrate, $16 \mathrm{~g} \mathrm{~L}^{-1} \mathrm{NaOH}$ ) were added, vortexed, and placed at $100^{\circ} \mathrm{C}$ for $5 \mathrm{~min}$. The tubes were then cooled to room temperature and $5 \mathrm{~mL}$ of distilled water were added. The tubes were vortexed, and absorbance was recorded at $540 \mathrm{~nm}$ in a UV/Vis spectrophotometer (UV-1800, Shimadzu, Kyoto, Japan) and quantified using D-glucose as a standard.

\subsection{Determination of Ethanol and Glycerol Content}

Ethanol and glycerol were determined by an HPLC Shimadzu chromatography system (Shimadzu Corp., Germany) equipped with a Nucleogel ION 300 OA column (Macherey-Nagel, Germany) [14].

\section{6. $p H$, Volatile Acidity, and Total Acidity}

The $\mathrm{pH}$ values were determined by portable, electronic $\mathrm{pH}$-meter (SensoDirect $\mathrm{pH}$ 110, AQUALYTIC, Dortmund, Germany). Total and volatile acidities were determined using the OIV-MA-AS313-01 and OIV-MA-AS313-02 methods, respectively [15].

\subsection{Determination of Total Flavonoid Content}

Total flavonoid content (TFC) was determined by the flavonoid-aluminum chloride $\left(\mathrm{AlCl}_{3}\right)$ complexation spectrophotometric method [16], with some modifications. Specifically, in a 5-mL Eppendorf tube, $2 \mathrm{~mL}$ of sample (appropriately diluted with distilled water), $200 \mu \mathrm{L}$ of $\mathrm{AlCl}_{3}$ solution (20 $\mathrm{g} \mathrm{L}^{-1} \mathrm{AlCl}_{3}$ in methanolic solution of $50 \mathrm{~mL} \mathrm{~L}^{-1}$ acetic acid), and $2.8 \mathrm{~mL}$ of $50 \mathrm{~mL} \mathrm{~L}^{-1}$ acetic acid in methanol were added, vortexed and allowed to stand at room temperature for $30 \mathrm{~min}$. The absorbance was recorded at $415 \mathrm{~nm}$ in a UV/Vis spectrophotometer (UV-1800, Shimadzu, Kyoto, Japan) and quantified using quercetin as a standard.

\subsection{Determination of Total Phenolic Content}

Total phenolic content (TPC) was determined by the Folin-Ciocalteau method [17], with some modifications. Specifically, in a 5-mL Eppendorf tube, $3.95 \mathrm{~mL}$ of distilled water, $50 \mu \mathrm{L}$ of sample (appropriately diluted with distilled water), and $250 \mu \mathrm{L}$ of Folin-Ciocalteau reagent were added and vortexed. After $1 \mathrm{~min}, 750 \mu \mathrm{L}$ of $200 \mathrm{~g} \mathrm{~L}^{-1}$ sodium carbonate were added, vortexed, and allowed to stand at room temperature in darkness, for $120 \mathrm{~min}$. The absorbance was recorded at $750 \mathrm{~nm}$ in a UV/Vis spectrophotometer (UV-1800, Shimadzu, Kyoto, Japan) and quantified using gallic acid as a standard.

\subsection{Determination of Free Radical-Scavenging Activity}

Free radical-scavenging activity was determined using the free radical $\mathrm{DPPH}^{\bullet}(2,2$ diphenyl-1-picrylhydrazyl) method [17], with some modifications. Specifically, in a 5-mL Eppendorf microtube, $125 \mu \mathrm{L}$ of sample (appropriately diluted with distilled water) and $4.875 \mathrm{~mL}$ of DPPH ${ }^{\bullet}$ solution were added, vortexed and allowed to stand at room temperature in darkness, for $30 \mathrm{~min}$. The absorbance 
of samples and blank (no sample) were recorded at $515 \mathrm{~nm}$ in a UV/Vis spectrophotometer (UV-1800, Shimadzu, Kyoto, Japan) and quantified using Trolox as a standard.

\subsection{Determination of Total Monomeric Anthocyanin Content}

Total monomeric anthocyanin content (TMAC) was determined using the $\mathrm{pH}$ differential method [18], with some modifications. Specifically, in a 5-mL Eppendorf tube, $5 \mathrm{~mL}$ of sample (appropriately diluted with $0.025 \mathrm{M}$ potassium chloride buffer $(\mathrm{pH}$ 1.0)) was added, vortexed, and allowed to stand at room temperature for $20 \mathrm{~min}$. Additionally, in a 5-mL Eppendorf tube, $5 \mathrm{~mL}$ of sample (appropriately diluted with $0.4 \mathrm{M}$ sodium acetate buffer ( $\mathrm{pH} 4.5$ )) was added, vortexed, and allowed to stand at room temperature for $20 \mathrm{~min}$. The absorbance was recorded at 520 and $700 \mathrm{~nm}$ in a UV/Vis spectrophotometer (UV-1800, Shimadzu, Kyoto, Japan). Results were expressed as mg cyanidin-3-glucoside equivalents (Cy3GE) $\mathrm{L}^{-1}$ according to the following equation: cyanidin $-3-$ glucoside $\left(m g L^{-1}\right)=\frac{A * M W * D F * 10^{3}}{\varepsilon * 1}$, where $\mathrm{A}=\left(\mathrm{A}_{520 \mathrm{~nm}}-\mathrm{A}_{700 \mathrm{~nm}}\right) \mathrm{pH} 1.0-\left(\mathrm{A}_{520 \mathrm{~nm}}-\mathrm{A}_{700 \mathrm{~nm}}\right)$ $\mathrm{pH} 4.5$; MW (Molecular Weight) $=449.2 \mathrm{~g} \mathrm{~mol}^{-1}$ for cyanidin-3-glucoside, DF (Dilution Factor), $10^{3}$ $=$ factor for conversion from $\mathrm{g}$ to $\mathrm{mg}$ and $\varepsilon$ (molar extinction coefficient) $=26900 \mathrm{~L} \mathrm{~mol}^{-1} \mathrm{~cm}^{-1}$ for cyanidin-3-glucoside.

\subsection{Determination of Yeast Assimilable Nitrogen}

Yeast assimilable nitrogen (YAN) was determined following the formol method [19].

\subsection{HS-SPME GC/MS Analysis}

Pomegranate alcoholic beverage samples from fermentations carried out at 15 and $25{ }^{\circ} \mathrm{C}$ were subjected to headspace solid-phase microextraction (HS-SPME) GC/MS analysis using a GC/MS (6890N GC, 5973 NetworkedMS MSD, Agilent Technologies, Santa Clara, CA, USA) equipped with a HP-5MS column ( $30 \mathrm{~m}, 0.25 \mathrm{~mm}$ i.d., $0.25 \mu \mathrm{m}$ film thickness, Agilent Technologies, Santa Clara, CA, USA) as recently described [20].

\subsection{Odor Activity Value (OAV)}

The OAV was calculated as the ratio between the concentration of an individual compound (detected in the present study) and the perception threshold found in the literature.

\subsection{Statistical Analysis}

The results were analyzed statistically by ANOVA. Bonferroni post-hoc test was used to determine significant differences among results (Statistica version 12.0, StatSoft Inc., Tulsa, OK, USA). The principal component analysis (PCA) algorithm was computed using XLSTAT 2015.1 [14].

\section{Results and Discussion}

In the present study, commercial pomegranate juice (sugars $128.4 \pm 0.1 \mathrm{~g} \mathrm{~L}^{-1} ; \mathrm{pH} 3.12 \pm 0.01$; acidity $16.0 \pm 0.1 \mathrm{~g}$ citric acid $\mathrm{L}^{-1}$; YAN $146.6 \pm 4.4 \mathrm{mg}$ nitrogen $\mathrm{L}^{-1}$ ) was used for the production of PABs after fermentation with different yeast strains. There is no specific yeast strain designed for pomegranate fermentation and therefore, the selection of appropriate yeast is very crucial. In order to deal with this gap in the literature, the aim of the present study was to evaluate different commercial yeast strains that are usually used in well-known fermented products like wine, beer, and cider and select the most appropriate for pomegranate fermentation. In addition, two fermentation temperatures, 15 and $25^{\circ} \mathrm{C}$ were selected, in order to evaluate each yeast performance. These temperatures are the usual used in winemaking (near $15{ }^{\circ} \mathrm{C}$ for white wines and near $25^{\circ} \mathrm{C}$ for red wines), and they have been proved ideal to compare the volatile profile of different yeasts [21,22]. Fermentations near $15^{\circ} \mathrm{C}$ benefit the sensory quality of wines since yeasts produce several alcohols and acetates and the loss of aroma is minimized [23], while $25^{\circ} \mathrm{C}$ favors the growth of S. cerevisiae [24]. 


\subsection{Physicochemical Characteristics}

The fermentation behavior of each yeast strain is presented in Figure 1, where sugar consumption and $\mathrm{CO}_{2}$ release are reported during fermentation. No significant differences are reported apart from a slight delay in the completion of fermentation by WB06.
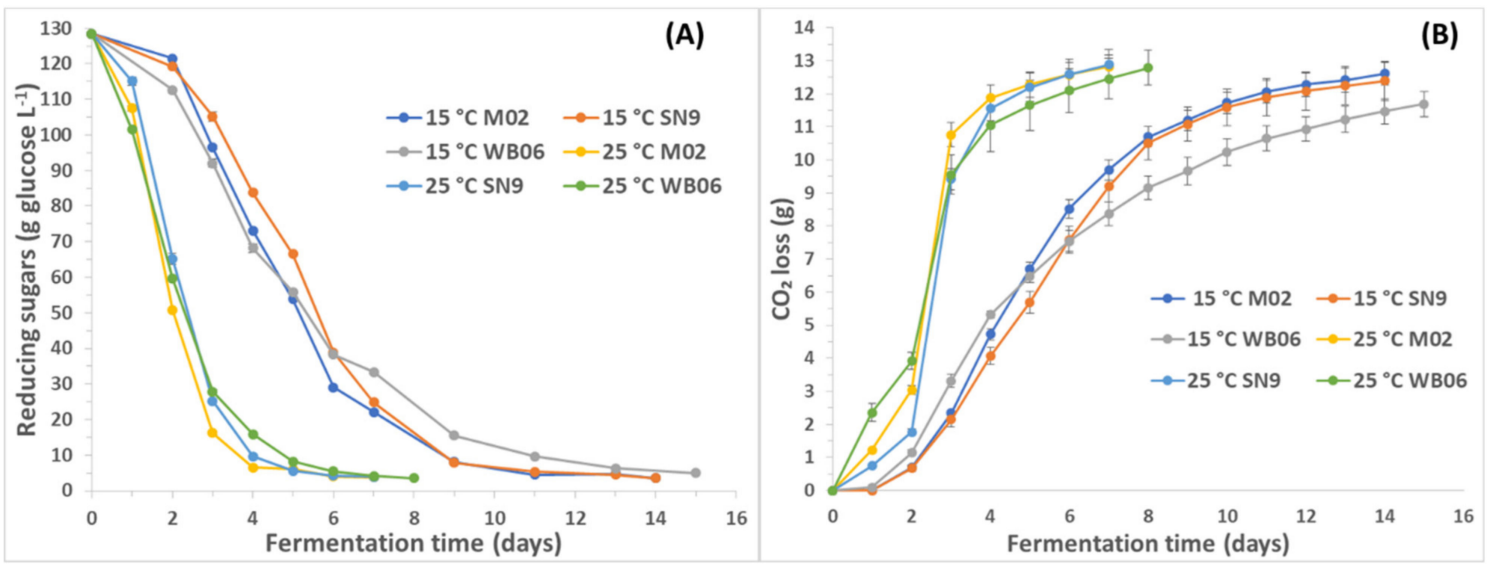

Figure 1. Effect of yeast strain and temperature on fermentation kinetics (reducing sugars $(\mathbf{A})$ and $\mathrm{CO}_{2}$ loss (B)) of PABs.

Table 1 summarizes the effects of yeast and fermentation temperature on the physicochemical characteristics of PABs, in comparison with the characteristics of the initial pomegranate juice.

Higher amounts of residual sugars were detected in PAB with WB06 yeast at both temperatures. It can also be deduced that at $15^{\circ} \mathrm{C}$ yeasts consumed less sugars in comparison with $25^{\circ} \mathrm{C}$, a fact that can be due to the temperature stress that yeasts underwent. However, all effects seemed to be significant $(p<0.05)$, while it appeared that the effect of temperature was more significant for yeasts M02 and WB06.

Ethanol content was affected significantly by yeasts but not by temperature. Also, a combined effect of yeast and temperature was reported. Alcohol concentrations are not in full accordance with other studies, as Andreu-Sevilla et al. [11] observed final concentrations of $8.30-9.05 \% \mathrm{v} / \mathrm{v}$, while in the present study, the values were lower (5.6-7.0\% v/v). However, this characteristic is tightly related with the initial sugar content of the juice. Moreover, the effect of yeast appeared to be significant at $15^{\circ} \mathrm{C}$, as fermentations with WB06 led to significantly lower concentrations, while at $25^{\circ} \mathrm{C}$ no significant differences were observed $(p>0.05)$.

Glycerol is a secondary product of Saccharomyces cerevisiae fermentation, a non-volatile alcohol that exclusively affects taste and texture, as it increases sweetness and fullness [25]. All yeasts examined presented a similar pattern of glycerol production in fermentations at $25^{\circ} \mathrm{C}$, whereas all findings were significantly higher in comparison with other studies [26]. This pattern is confirmed statistically, revealing the significant effect of temperature, yeast, and both of them. Additionally, it appears that the effect of temperature was not significant $(p>0.05)$ only in the case of fermentation with M02, as a similar amount of glycerol was produced at both temperatures. Similar concentrations of glycerol (4.4-5.2 $\mathrm{g} \mathrm{L}^{-1}$ ), produced by $S$. cerevisiae, have been reported in an alcoholic beverage from dragon fruit [5], however, this yeast is capable of producing even higher amounts in the case of mead fermentation $\left(>9.5 \mathrm{~g} \mathrm{~L}^{-1}\right)$ [6].

A crucial factor for all types of fermentation is $\mathrm{pH}$ because it affects the growth of yeasts and characteristics of the final product, such as color and taste. The $\mathrm{pH}$ range of pomegranate juice is 2.9-3.7 and varies according to different pomegranate variety [26-30]. In the present study, the $\mathrm{pH}$ value of the juice used was 3.12, which is similar with other studies with cv Wonderful, reporting the usual $\mathrm{pH}$ values between 2.9 and 3.2 [27,29]. After fermentation, a slight reduction in $\mathrm{pH}$ was observed, especially at $25^{\circ} \mathrm{C}$ resulting in a final $\mathrm{pH}$ value of $3.10-3.12$ at $15^{\circ} \mathrm{C}$ and $3.05-3.07$ at $25^{\circ} \mathrm{C}$. Similar 
$\mathrm{pH}$ values (3.12) have been observed on fermented beverages from Wonderful variety in previous studies [29]. Fermentations at $15{ }^{\circ} \mathrm{C}$ did not alter $\mathrm{pH}$ significantly, in contrast with fermentations at $25^{\circ} \mathrm{C}$. In conclusion, the effect of yeast was not significant at both temperatures, and only temperature significantly affected the $\mathrm{pH}$ values.

Table 1. Effect of yeast and fermentation temperature on the physicochemical characteristics of pomegranate alcoholic beverages.

\begin{tabular}{|c|c|c|c|c|c|c|}
\hline \multirow{2}{*}{ Analyses } & \multirow{2}{*}{ Yeast Strain } & \multicolumn{2}{|c|}{ Fermentation Temperature } & \multicolumn{3}{|c|}{ Significance of Effect } \\
\hline & & $15^{\circ} \mathrm{C}$ & $25{ }^{\circ} \mathrm{C}$ & Temp. & Yeast & Comb. \\
\hline \multirow{4}{*}{ 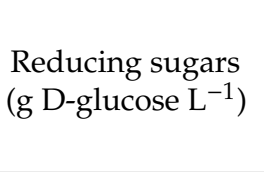 } & PJ & \multicolumn{2}{|c|}{$128.4 \pm 0.1$} & \multirow{4}{*}{$* * *$} & \multirow{4}{*}{$* * *$} & \multirow{4}{*}{$* * *$} \\
\hline & M02 & $5.1 \pm 0.3^{\mathrm{b}, \mathrm{A}}$ & $4.0 \pm 0.1^{\mathrm{b}, \mathrm{B}}$ & & & \\
\hline & SN9 & $4.4 \pm 0.2^{\mathrm{c}, \mathrm{A}}$ & $4.0 \pm 0.2^{\mathrm{b}, \mathrm{B}}$ & & & \\
\hline & WB06 & $10.5 \pm 0.2^{\mathrm{a}, \mathrm{A}}$ & $4.7 \pm 0.1^{\mathrm{a}, \mathrm{B}}$ & & & \\
\hline \multirow{4}{*}{$\begin{array}{l}\text { Ethanol } \\
(\% \mathrm{v} / \mathrm{v})\end{array}$} & PJ & & & \multirow{4}{*}{ ns } & \multirow{4}{*}{ * } & \multirow{4}{*}{ * } \\
\hline & M02 & $6.9 \pm 0.1^{\mathrm{a}, \mathrm{A}}$ & $6.5 \pm 0.2^{\mathrm{a}, \mathrm{A}}$ & & & \\
\hline & SN9 & $6.8 \pm 0.1^{\mathrm{a}, \mathrm{A}}$ & $7.0 \pm 0.1^{\mathrm{a}, \mathrm{A}}$ & & & \\
\hline & WB06 & $5.6 \pm 0.2^{\mathrm{b}, \mathrm{A}}$ & $6.6 \pm 0.1^{\mathrm{a}, \mathrm{B}}$ & & & \\
\hline \multirow{4}{*}{$\begin{array}{l}\text { Glycerol } \\
\left(\mathrm{g} \mathrm{L}^{-1}\right)\end{array}$} & PJ & & & \multirow{4}{*}{$* *$} & \multirow{4}{*}{ ** } & \multirow{4}{*}{$* *$} \\
\hline & M02 & $5.75 \pm 0.07^{\mathrm{a}, \mathrm{A}}$ & $5.65 \pm 0.64^{\mathrm{a}, \mathrm{A}}$ & & & \\
\hline & SN9 & $5.05 \pm 0.07^{\mathrm{b}, \mathrm{A}}$ & $6.05 \pm 0.50^{\mathrm{a}, \mathrm{B}}$ & & & \\
\hline & WB06 & $2.65 \pm 0.07^{c, B}$ & $5.80 \pm 0.57^{\mathrm{a}, \mathrm{A}}$ & & & \\
\hline \multirow{4}{*}{$\mathrm{pH}$} & $\mathrm{PJ}$ & \multicolumn{2}{|c|}{$3.12 \pm 0.01^{\mathrm{a}, \mathrm{A}}$} & \multirow{4}{*}{$* * *$} & \multirow{4}{*}{ ns } & \multirow{4}{*}{ ns } \\
\hline & M02 & $3.11 \pm 0.01^{\mathrm{a}, \mathrm{A}}$ & $3.07 \pm 0.01^{\mathrm{b}, \mathrm{B}}$ & & & \\
\hline & SN9 & $3.12 \pm 0.01^{\mathrm{a}, \mathrm{A}}$ & $3.06 \pm 0.01^{\mathrm{b}, \mathrm{B}}$ & & & \\
\hline & WB06 & $3.10 \pm 0.01^{\mathrm{a}, \mathrm{A}}$ & $3.05 \pm 0.01^{\mathrm{b}, \mathrm{B}}$ & & & \\
\hline \multirow{4}{*}{ 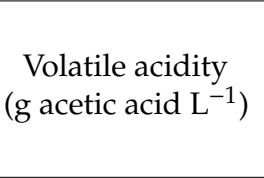 } & PJ & \multicolumn{2}{|c|}{$0.11 \pm 0.01^{\mathrm{a}, \mathrm{A}}$} & \multirow{4}{*}{ * } & \multirow{4}{*}{$* * *$} & \multirow{4}{*}{ ns } \\
\hline & M02 & $0.76 \pm 0.05^{\mathrm{c}, \mathrm{B}}$ & $0.69 \pm 0.04^{\mathrm{b}, \mathrm{B}}$ & & & \\
\hline & SN9 & $0.85 \pm 0.05^{\mathrm{c}, \mathrm{B}}$ & $0.84 \pm 0.02^{\mathrm{c}, \mathrm{B}}$ & & & \\
\hline & WB06 & $0.33 \pm 0.01^{\mathrm{b}, \mathrm{B}}$ & $0.21 \pm 0.01^{\mathrm{a}, \mathrm{A}}$ & & & \\
\hline \multirow{4}{*}{$\begin{array}{l}\text { Titratable acidity } \\
\left(\mathrm{g} \text { citric acid } \mathrm{L}^{-1}\right)\end{array}$} & PJ & 16.0 & $\mathrm{a}, \mathrm{A}$ & \multirow{4}{*}{ ns } & \multirow{4}{*}{ ns } & \multirow{4}{*}{ ns } \\
\hline & M02 & $16.4 \pm 0.6^{\mathrm{a}, \mathrm{A}}$ & $17.0 \pm 0.2^{\mathrm{a}, \mathrm{A}}$ & & & \\
\hline & SN9 & $16.6 \pm 0.4^{\mathrm{a}, \mathrm{A}}$ & $16.5 \pm 0.6^{\mathrm{a}, \mathrm{A}}$ & & & \\
\hline & WB06 & $16.2 \pm 0.3^{\mathrm{a}, \mathrm{A}}$ & $16.8 \pm 0.5^{\mathrm{a}, \mathrm{A}}$ & & & \\
\hline
\end{tabular}

abcd Different letters at the same parameter and temperature (vertically-effect of yeast) indicate significant differences between means $(p<0.05)$. ABC Different letters at the same parameter and different temperature (horizontally-effect of temperature) indicate significant differences between means $(p<0.05)$. PJ, pomegranate juice; ns: not significant $(p>0.05) ;{ }^{*}: p<0.05 ; * *: p<0.01 ;{ }^{* * *}: p<0.001$; Temp, temperature; Comb, combined effect.

Fermentations with SN9 yeast led to the highest volatile acidity $\left(0.83-0.88 \mathrm{~g}\right.$ acetic acid $\left.\mathrm{L}^{-1}\right)$, followed by M02 yeast (0.71-0.76 $\mathrm{g}$ acetic acid $\left.\mathrm{L}^{-1}\right)$ and WB06 yeast $\left(0.22-0.33 \mathrm{~g}\right.$ acetic acid $\left.\mathrm{L}^{-1}\right)$. However, all final products comply with the regulations concerning volatile acidity $\left(\leq 1 \mathrm{~g}\right.$ acetic acid $\mathrm{L}^{-1}$, of the Greek Government [31]), whereas other studies present slightly higher volatile acidities (0.9-1.0 g acetic acid $\mathrm{L}^{-1}$ ) [28]. In general, the results showed that volatile acidity is a characteristic that it is mainly affected by the yeast used for the fermentation, and to a lesser extent, by the fermentation temperature.

Total acidity did not increase significantly after fermentation, with the higher value presented at fermentations at $25^{\circ} \mathrm{C}\left(\mathrm{M} 02,17.0 \pm 0.2 \mathrm{~g}\right.$ citric acid $\left.\mathrm{L}^{-1}\right)$. Similarly, all final products complied with the regulations of the Greek Government [31] concerning total acidity ( $\geq 6 \mathrm{~g}$ citric acid/L), and findings of the current study coincided with other similar studies [29]. However, pomegranate variety is a major factor affecting this characteristic. Different pomegranate varieties result in PAB with acidities from 4.6-20.2 $\mathrm{g}$ citric acid $\mathrm{L}^{-1}$ [29]. Statistically, the non-significance $(p>0.05)$ of all parameters at all cases is confirmed. In the present study, no significant differences were observed between PAB and initial 
pomegranate juice. The initial acidity $\left(16 \mathrm{~g}\right.$ citric acid $\left.\mathrm{L}^{-1}\right)$ that was detected in the present study, it is the usual $\left(15.4-17.5 \mathrm{~g}\right.$ citric acid $\left.\mathrm{L}^{-1}\right)$ reported in juices of pomegranate $\mathrm{cv}$ Wonderful $[27,29]$.

\subsection{Antioxidant Activity and Phenolic Compounds}

Table 2 summarizes the effects of yeast and fermentation temperature on the antioxidant activity and phenolic content of PABs, in comparison with the characteristics of the initial pomegranate juice.

Table 2. Effect of yeast and fermentation temperature on the antioxidant activity and phenolic compounds of pomegranate alcoholic beverages.

\begin{tabular}{|c|c|c|c|c|c|c|}
\hline \multirow{2}{*}{ Analyses } & \multirow{2}{*}{ Yeast Strain } & \multicolumn{2}{|c|}{ Fermentation Temperature } & \multicolumn{3}{|c|}{ Significance of Effect } \\
\hline & & $15^{\circ} \mathrm{C}$ & $25^{\circ} \mathrm{C}$ & Temp. & Yeast & Comb. \\
\hline \multirow{4}{*}{$\begin{array}{l}\text { Total flavonoid content } \\
\qquad\left(\mathrm{mg} \mathrm{QE} \mathrm{L}^{-1}\right)\end{array}$} & PJ & \multicolumn{2}{|c|}{$320.2 \pm 4.5^{\mathrm{a}, \mathrm{A}}$} & \multirow{4}{*}{$* * *$} & \multirow{4}{*}{$* * *$} & \multirow{4}{*}{ ns } \\
\hline & M02 & $\begin{array}{l}106.7 \pm \\
26.4^{\mathrm{b}, \mathrm{C}}\end{array}$ & $\begin{array}{l}174.5 \pm \\
19.4^{\mathrm{b}, \mathrm{B}}\end{array}$ & & & \\
\hline & SN9 & $\begin{array}{l}78.0 \pm \\
34.3^{\mathrm{b}, \mathrm{C}}\end{array}$ & $\begin{array}{l}148.0^{ \pm} \pm \\
16.4^{\mathrm{c}, \mathrm{B}}\end{array}$ & & & \\
\hline & WB06 & $\begin{array}{l}96.2 \pm \\
27.8^{\mathrm{b}, \mathrm{C}}\end{array}$ & $\begin{array}{l}173.0 \pm \\
11.7^{\mathrm{b}, \mathrm{B}}\end{array}$ & & & \\
\hline \multirow{4}{*}{$\begin{array}{l}\text { Total phenolic content } \\
\quad\left(\mathrm{mg} \mathrm{GAE} \mathrm{L}^{-1}\right)\end{array}$} & PJ & \multicolumn{2}{|c|}{$2470.1 \pm 14.8^{\mathrm{a}, \mathrm{A}}$} & \multirow{4}{*}{ ns } & \multirow{4}{*}{ ns } & \multirow{4}{*}{$* *$} \\
\hline & M02 & $\begin{array}{l}926.9 \pm \\
357.8^{\mathrm{b}, \mathrm{B}}\end{array}$ & $\begin{array}{l}817.5 \pm \\
98.4^{\mathrm{c}, \mathrm{B}}\end{array}$ & & & \\
\hline & SN9 & $\begin{array}{l}807.2 \pm \\
385.1^{\mathrm{b}, \mathrm{B}}\end{array}$ & $\begin{array}{c}834.2 \pm \\
86.8^{\mathrm{c}, \mathrm{B}}\end{array}$ & & & \\
\hline & WB06 & $\begin{array}{l}703.8 \pm \\
69.2^{\mathrm{b}, \mathrm{C}}\end{array}$ & $\begin{array}{l}1027.3 \pm \\
197.8^{\mathrm{b}, \mathrm{B}}\end{array}$ & & & \\
\hline \multirow{4}{*}{$\begin{array}{c}\mathrm{DPPH}^{\bullet} \\
(\mathrm{mM} \text { TRE})\end{array}$} & PJ & \multicolumn{2}{|c|}{$17.6 \pm 0.1^{\mathrm{a}, \mathrm{A}}$} & \multirow{4}{*}{$* *$} & \multirow{4}{*}{ ns } & \multirow{4}{*}{ ns } \\
\hline & M02 & $15.5 \pm 1.4^{\mathrm{b}, \mathrm{A}}$ & $15.6 \pm 1.5^{\mathrm{b}, \mathrm{A}}$ & & & \\
\hline & SN9 & $14.4 \pm 1.1^{\mathrm{b}, \mathrm{C}}$ & $15.7 \pm 1.0^{\mathrm{b}, \mathrm{B}}$ & & & \\
\hline & WB06 & $15.3 \pm 0.9^{b, c}$ & $16.1 \pm 0.5^{\mathrm{b}, \mathrm{B}}$ & & & \\
\hline \multirow{4}{*}{$\begin{array}{l}\text { Total monomeric } \\
\text { anthocyanin content } \\
\left(\mathrm{mg} \mathrm{Cy3GE} \mathrm{L}{ }^{-1}\right)\end{array}$} & PJ & 105.2 & $0.1^{\mathrm{a}, \mathrm{A}}$ & \multirow{4}{*}{$* * *$} & \multirow{4}{*}{$* * *$} & \multirow{4}{*}{$* * *$} \\
\hline & M02 & $75.0 \pm 3.4^{\mathrm{b}, \mathrm{C}}$ & $78.2 \pm 2.1^{b, B}$ & & & \\
\hline & SN9 & $70.4 \pm 1.1^{\mathrm{c}, \mathrm{C}}$ & $78.7 \pm 2.0^{\mathrm{b}, \mathrm{B}}$ & & & \\
\hline & WB06 & $74.1 \pm 0.7^{\mathrm{b}, \mathrm{B}}$ & $69.6 \pm 2.6^{c, C}$ & & & \\
\hline
\end{tabular}

\footnotetext{
abc Different letters at the same parameter and temperature (vertically-effect of yeast) indicate significant differences between means $(p<0.05)$. ${ }^{A B C}$ Different letters at the same parameter and different temperature (horizontally-effect of temperature) indicate significant differences between means $(p<0.05)$. PJ, pomegranate juice; $\mathrm{QE}$, quercetin equivalents; GAE, gallic acid equivalents; TRE: trolox equivalents; Cy3GE, cyanidin-3-glucoside equivalents; ns, not significant $(p>0.05) ;{ }^{*}: p<0.05 ;{ }^{* *}: p<0.01 ;{ }^{* * *}: p<0.001$; Temp, temperature; Comb, combined effect.
}

Pomegranate juice flavonoids have been extensively studied, with research suggesting that juice can contain amounts ranging from 45 to $636 \mathrm{mg} \mathrm{QE} \mathrm{L}^{-1}$ [32,33]. Pomegranate juice used in this study appeared to fall within the expected values of flavonoid content $\left(320.2 \pm 4.5 \mathrm{mg} \mathrm{QE} \mathrm{L}^{-1}\right)$, a concentration which decreased after fermentation by approximately $70 \%$ at $15{ }^{\circ} \mathrm{C}$ and approximately $50 \%$ at $25^{\circ} \mathrm{C}$. Additionally, it can be concluded that both the effect of temperature and the effect of yeast were significant $(p<0.05)$. These results are in accordance with previous studies reporting a reduction in TFC after fermentation at $25{ }^{\circ} \mathrm{C}$ from $30 \%$ to up to $63 \%$ [28].

Phenolic compounds contribute to the sensory characteristics of a product, as they affect parameters such as aroma, color, and flavor [34]. Pomegranate juice's phenolic content $\left(2470.1 \pm 14.8 \mathrm{mg} \mathrm{GAE} \mathrm{L}^{-1}\right)$ is in accordance with other studies suggesting that it can contain amounts in a wide range of 458-7429 $\mathrm{mg} \mathrm{L}^{-1}$ [32,33], and up to 3900 for Wonderful cultivar [29]. This concentration decreased after fermentation at $15^{\circ} \mathrm{C}$ in the same way as flavonoids, namely by approximately $70 \%$, whereas it decreased by approximately $65 \%$ at $25^{\circ} \mathrm{C}$. This decrease can be attributed to hydrolysis and oxidation reactions of polyphenols during fermentation, to condensation and polymerization reactions, as well as to adsorption of phenolics to the yeast cells $[34,35]$. Similarly, all effects were significant in all cases 
$(p<0.05)$. Previous studies reported a decrease in TPC of PAB after fermentation ranging from $7 \%$ up to $42 \%[28,29]$.

Free radical-scavenging activity $\left(\mathrm{DPPH}^{\bullet}\right)$ of the juice appeared to be equal to $17.6 \mathrm{mM}$ TRE, with fermentations at $15{ }^{\circ} \mathrm{C}$ inducing a $15 \%$ decrease, and fermentations at $25{ }^{\circ} \mathrm{C}$ inducing a $10 \%$ decrease, approximately. The antioxidant activity of pomegranate juice depends greatly on the variety of pomegranate used [29]. The present study results are in accordance with those of a previous study with fermented PAB from Wonderful variety, reporting a decrease up to $16 \%$ [29]. In other PABs, which were produced using juices from other pomegranate varieties (Hicaz and Mollar de Elche), significantly smaller free radical-scavenging activities were reported $[29,30]$. It is possible that the decrease in free radical-scavenging activity observed after fermentation is due to oxidation reactions that took place between phenolics and/or other molecules [28]. It has been proved that fermented fruit juice production procedures can potentially alter the antioxidant activity of the product [36-38]. Temperature significantly affected the antioxidant activity while the effect of yeast was not significant.

The effect of yeast on the phenolic content and free radical-scavenging activity has been vastly studied on wine. Results seem to be contradicting, with researchers supporting that the effect of yeast on these characteristics is significant [39-42], while others support that there is no significant effect $[43,44]$.

Finally, as far as monomeric anthocyanins are concerned, initial juice and PAB appeared to contain relatively high amounts of monomeric anthocyanins. The juice contained approximately $105.2 \mathrm{mg}$ Cy3GE L $\mathrm{L}^{-1}$, while fermentation caused a decrease of approximately $30 \%$ at both temperatures. Many researchers have studied the anthocyanin content of pomegranate juice and its fermented counterpart, suggesting a reduction after fermentation, usually 50\% [4,28] and $46 \%$ for Wonderful variety [29]. The decrease of monomeric anthocyanin content observed after fermentation is probably due to the polymerization of monomeric anthocyanins, as polymeric anthocyanins cannot be detected by the $\mathrm{pH}$ differential method due to the fact that they are resistant to color change with change in $\mathrm{pH}$ and absorb at both values $[18,45]$. Additionally, this decrease can be due to degradation reactions and interactions between anthocyanins and other phenolic compounds [46]. Especially, during fermentation, the above-mentioned phenomena may be attributed to the condensation of anthocyanins with acetaldehyde, to enzymes like $\beta$-glucosidases that degrade anthocyanins, and to direct oxidation of anthocyanins by $\mathrm{O}_{2}[29,38,47]$. Statistically, all effects appeared to be significant.

\subsection{Volatile Composition}

The composition of volatile compounds of PAB fermented with different yeasts (M02, SN9, and WB06) is presented in Table 3. A total of 30 different volatile compounds were identified, with the produced PABs containing 15 esters, 4 organic acids, 8 alcohols, and 3 terpenes, at concentrations that varied between samples. The most dominant compound group was found to be alcohols, followed by esters, organic acids, and terpenes, with the exception of fermentations with WB06 at $15{ }^{\circ} \mathrm{C}$, where the concentration of esters was higher than that of alcohols. The majority of identified compounds are verified by literature and other studies on pomegranate and its juice/beverages [11,48-50]. However, there are many factors that can affect the concentration of these compounds, such as the fruit genotype and composition, the level of maturity at harvest, environmental and storage conditions, winemaking techniques, etc. [51].

The volatile analysis of the commercial pomegranate juice revealed a very low aromatic profile (mainly ethyl acetate and some alcohols were detected), as was already known by previous studies [52]. Industrial processing (including pasteurization) alters the volatile profile of juices, and therefore the majority of volatile compounds present in fresh juice are absent in commercial juices [49]. Therefore, it can be easily concluded that the majority of the compounds presented in Table 3 are a result of yeast metabolism and fermentation. 
Table 3. Effect of yeast and fermentation temperature on aroma-related compounds $\left(\mathrm{mg} \mathrm{L}^{-1}\right)$ of pomegranate alcoholic beverages as detected by GC/MS analysis.

\begin{tabular}{|c|c|c|c|c|c|c|}
\hline \multirow{3}{*}{ Compound } & \multicolumn{6}{|c|}{ Yeast Strain } \\
\hline & \multicolumn{2}{|c|}{ M02 } & \multicolumn{2}{|c|}{ SN9 } & \multicolumn{2}{|c|}{ WB06 } \\
\hline & $15^{\circ} \mathrm{C}$ & $25^{\circ} \mathrm{C}$ & $15^{\circ} \mathrm{C}$ & $25^{\circ} \mathrm{C}$ & $15^{\circ} \mathrm{C}$ & $25^{\circ} \mathrm{C}$ \\
\hline Esters & & & & & & \\
\hline ethyl acetate & $3.14 \pm 0.23$ & $3.10 \pm 0.99$ & $5.90 \pm 2.12$ & $3.63 \pm 1.10$ & $3.40 \pm 0.15$ & $3.16 \pm 0.91$ \\
\hline ethyl propanoate & $0.03 \pm 0.04$ & $0.15 \pm 0.07$ & $0.05 \pm 0.07$ & $0.20 \pm 0.00$ & $0.20 \pm 0.00$ & $\mathrm{Nd}$ \\
\hline ethyl butanoate & $0.47 \pm 0.07$ & $0.30 \pm 0.00$ & $0.65 \pm 0.49$ & $0.25 \pm 0.07$ & $0.46 \pm 0.08$ & $0.45 \pm 0.07$ \\
\hline 3-methylbutyl acetate & $1.06 \pm 0.02$ & $2.00 \pm 0.85$ & $1.17 \pm 0.18$ & $1.63 \pm 0.32$ & $1.60 \pm 0.56$ & $2.23 \pm 0.04$ \\
\hline 2-methylbutyl acetate & $0.17 \pm 0.01$ & $0.23 \pm 0.07$ & $0.08 \pm 0.11$ & $0.22 \pm 0.02$ & $0.11 \pm 0.11$ & $0.13 \pm 0.04$ \\
\hline ethyl hexanoate & $2.42 \pm 0.05$ & $2.06 \pm 1.05$ & $3.45 \pm 0.92$ & $3.00 \pm 0.42$ & $4.20 \pm 0.57$ & $7.99 \pm 6.38$ \\
\hline hexyl acetate & $\mathrm{Nd}$ & $0.07 \pm 0.03$ & $\mathrm{Nd}$ & $0.40 \pm 0.40$ & $\mathrm{Nd}$ & $\mathrm{Nd}$ \\
\hline ethyl octanoate & $3.90 \pm 0.00^{\mathrm{ab}}$ & $3.15 \pm 1.48^{\mathrm{a}}$ & $6.15 \pm 0.78^{\mathrm{ab}}$ & $4.58 \pm 1.39^{\mathrm{ab}}$ & $13.45 \pm 2.19^{b}$ & $8.75 \pm 4.03^{\mathrm{ab}}$ \\
\hline ethyl phenylacetate & $0.08 \pm 0.04$ & $0.11 \pm 0.06$ & $0.10 \pm 0.00$ & $0.09 \pm 0.03$ & $\mathrm{Nd}$ & $0.27 \pm 0.19$ \\
\hline 2-phenylethyl acetate & $0.23 \pm 0.25$ & $0.70 \pm 0.44$ & $0.54 \pm 0.08$ & $0.53 \pm 0.32$ & $1.14 \pm 0.40$ & $3.14 \pm 1.89$ \\
\hline ethyl 9-decanoate & $0.25 \pm 0.01$ & $\mathrm{Nd}$ & $0.30 \pm 0.28$ & $\mathrm{Nd}$ & $0.20 \pm 0.14$ & $\mathrm{Nd}$ \\
\hline ethyl decanoate & $1.10 \pm 0.03$ & $1.90 \pm 1.13$ & $2.06 \pm 0.08$ & $0.55 \pm 0.07$ & $6.15 \pm 3.04$ & $3.30 \pm 1.27$ \\
\hline ethyl dodecanoate & $1.18 \pm 0.54$ & $1.62 \pm 1.30$ & $0.70 \pm 0.00$ & $0.18 \pm 0.03$ & $3.10 \pm 1.13$ & $2.74 \pm 1.36$ \\
\hline ethyl tetradecanoate & $0.24 \pm 0.20$ & $0.50 \pm 0.42$ & $0.10 \pm 0.00$ & $0.08 \pm 0.04$ & $0.25 \pm 0.07$ & $0.15 \pm 0.07$ \\
\hline ethyl hexadecanoate & $0.32 \pm 0.31$ & $1.09 \pm 1.15$ & $0.35 \pm 0.07$ & $0.29 \pm 0.16$ & $0.35 \pm 0.21$ & $0.70 \pm 0.42$ \\
\hline Total esters & $14.58 \pm 1.46$ & $16.98 \pm 8.90$ & $21.60 \pm 4.97$ & $15.61 \pm 8.90$ & $34.59 \pm 5.99$ & $33.00 \pm 14.79$ \\
\hline \multicolumn{7}{|l|}{ Organic acids } \\
\hline octanoic acid & $3.89 \pm 1.15$ & $3.55 \pm 2.47$ & $5.75 \pm 0.92$ & $1.97 \pm 0.23$ & $7.75 \pm 3.18$ & $3.70 \pm 0.28$ \\
\hline decanoic acid & $2.05 \pm 1.06$ & $2.10 \pm 1.70$ & $2.60 \pm 0.57$ & $0.55 \pm 0.55$ & $5.85 \pm 4.17$ & $5.35 \pm 2.76$ \\
\hline dodecanoic acid & $0.52 \pm 0.52$ & $0.39 \pm 0.39$ & $\mathrm{Nd}$ & $\mathrm{Nd}$ & $0.59 \pm 0.23$ & $0.28 \pm 0.28$ \\
\hline hexadecanoic acid & $0.06 \pm 0.06$ & $8.23 \pm 8.23$ & $\mathrm{Nd}$ & $0.03 \pm 0.03$ & $\mathrm{Nd}$ & $\mathrm{Nd}$ \\
\hline $\begin{array}{c}\text { Total organic acids } \\
\text { Alcohols }\end{array}$ & \multicolumn{5}{|c|}{ Alcohols } & $9.33 \pm 2.08$ \\
\hline methyl-1-propanol & $0.17 \pm 0.23$ & $0.50 \pm 0.28$ & $0.17 \pm 0.17$ & $0.28 \pm 0.11$ & $0.19 \pm 0.19$ & $0.44 \pm 0.06$ \\
\hline 3-methyl-1-butanol & $10.87 \pm 0.57$ & $15.83 \pm 5.62$ & $15.63 \pm 5.05$ & $14.17 \pm 1.74$ & $17.10 \pm 2.03$ & $62.08 \pm 30.30$ \\
\hline 2-methyl-1-butanol & $4.20 \pm 0.28$ & $7.74 \pm 2.60$ & $3.96 \pm 0.93$ & $3.70 \pm 0.71$ & $5.18 \pm 0.69$ & $8.49 \pm 1.71$ \\
\hline 2,3-butanediol & $\mathrm{Nd}$ & $0.85 \pm 0.85$ & $0.70 \pm 0.70$ & $0.20 \pm 0.20$ & $0.03 \pm 0.03$ & $\mathrm{Nd}$ \\
\hline (Z)-3-hexen-1-ol & $0.17 \pm 0.01$ & $0.16 \pm 0.08$ & $0.15 \pm 0.07$ & $0.18 \pm 0.05$ & $0.10 \pm 0.10$ & $0.12 \pm 0.03$ \\
\hline 1-hexanol & $0.13 \pm 0.01$ & $0.18 \pm 0.03$ & $\mathrm{Nd}$ & $0.12 \pm 0.06$ & $0.05 \pm 0.05$ & $3.73 \pm 3.73$ \\
\hline 2-ethyl-1-hexanol & $0.12 \pm 0.03$ & $0.15 \pm 0.07$ & $\mathrm{Nd}$ & $0.05 \pm 0.05$ & $\mathrm{Nd}$ & $\mathrm{Nd}$ \\
\hline 2-phenylethanol & $2.25 \pm 0.91$ & $7.00 \pm 3.54$ & $3.50 \pm 1.98$ & $4.20 \pm 0.14$ & $9.40 \pm 4.67$ & $32.15 \pm 26.23$ \\
\hline Total alcohols & $17.89 \pm 0.99$ & $32.40 \pm 5.09$ & $24.11 \pm 6.78$ & $22.90 \pm 0.60$ & $32.03 \pm 2.81$ & $\begin{array}{c}107.01 \pm \\
63.46\end{array}$ \\
\hline $\begin{array}{l}\text { Terpenes } \\
\text { eucalyptol }\end{array}$ & $0.13 \pm 0.00$ & $0.12 \pm 0.07$ & $0.20 \pm 0.00$ & $0.11 \pm 0.11$ & $\mathrm{Nd}$ & $\mathrm{Nd}$ \\
\hline$\alpha$-terpineol & $\mathrm{Nd}$ & $\mathrm{Nd}$ & $\mathrm{Nd}$ & $0.10 \pm 0.10$ & $\mathrm{Nd}$ & $\mathrm{Nd}$ \\
\hline trans-nerolidol & $\mathrm{Nd}$ & $0.15 \pm 0.07^{\mathrm{a}}$ & $\mathrm{Nd}$ & $0.14 \pm 0.02^{\mathrm{a}}$ & $\mathrm{Nd}$ & $0.62 \pm 0.31^{b}$ \\
\hline Total terpenes & $0.13 \pm 0.01$ & $0.27 \pm 0.14$ & $0.20 \pm 0.00$ & $0.35 \pm 0.28$ & $\mathrm{Nd}$ & $0.62 \pm 0.31$ \\
\hline
\end{tabular}

${ }^{\mathrm{ab}}$ Different letters indicate significant differences between means $(p<0.05)$; $\mathrm{Nd}$, not detected; The concentration of each group of compounds is presented in bold.

\subsubsection{Esters}

Esters are compounds that can be found in fruits and vegetables and are significant aroma constituents responsible for these products' fruity notes. Ethyl acetate is one of the most known aromatic compounds of fruit and vegetables belonging in this group and is thought to present a sweet-fruity odor. Specifically, studies have reported the presence of ethyl acetate in pomegranate juice [52], while the high intensity of pomegranate berry and fruity notes are attributed to esters (mainly ethyl acetate and octyl acetate) [11]. In the present study, ethyl acetate was the second most abundant ester, and it was detected in all samples. In general, higher concentrations were observed at lower temperatures. It was also detected in commercial juice but in relatively low concentrations $\left(0.1 \mathrm{mg} \mathrm{L}^{-1}\right)$. Ethyl propanoate and ethyl hexanoate have also been previously reported in pomegranate juice [53], compounds that were found to deplete after pasteurization. Both esters were detected in the PABs, however, ethyl hexanoate in higher concentrations as a result of the action of yeasts. Ethyl butanoate is a compound that has been previously found in commercial pomegranate products at high relative 
percentages [49]. However, it has not been listed as an important volatile in pomegranate [54]. In the present study, no significant differences were observed either between yeasts or temperature used, in the concentration of ethyl butanoate, ranging from 0.25 to $0.65 \mathrm{mg} \mathrm{L}^{-1}$. 3-methylbutyl acetate and 2-methylbutyl acetate were detected in all samples, with the first detected in higher concentrations. Both of them have been isolated from fresh pomegranate juice and are thought to contribute towards a fruity aroma $[49,55]$. Ethyl octanoate was the ester with the highest concentration in all samples. In general, the highest concentrations were detected at lower temperatures. Regarding the effect of yeast, WB06 resulted in higher concentrations followed by SN9 and M02. Our results are in accordance with previous studies that also found ethyl octanoate to be the most abundant compound in pomegranate wines, responsible for fruity, green, and citrus aroma [11]. 2-phenylethyl acetate, detected in all samples but at higher concentrations by WB06, is characterized as key volatile of pomegranate arils, providing a flowery, fruity, and cooked apple aroma [56]. Ethyl phenylacetate (fruit and sweet aroma), ethyl dodecanoate, and ethyl hexadecanoate (wax aroma) were identified in low concentrations in all samples, and they are usually found in pomegranate wines and vinegars [57]. Ethyl 9-decanoate (detected in all samples at $15^{\circ} \mathrm{C}$ ), and ethyl decanoate (detected in all samples), have not been reported in pomegranate products before. However, they have been reported in prickly pear wines [58]. In general, the PAB that were produced by WB06 yeast, presented the highest concentrations of esters in both fermentation temperatures.

\subsubsection{Organic Acids}

Organic acids in beverages play an important role as far as flavor and taste are concerned. Firstly, they contribute to the development of sourness, while some of them possess their own characteristic flavor or aroma [59]. In wines, they are considered to contribute mainly to the complexity of aroma at concentrations not higher than their threshold values [60,61]. In the present study, four acids were detected, namely octanoic, decanoic, dodecanoic, and hexadecanoic acid. Octanoic and decanoic acids were detected in all samples, and they were the acids with the highest concentrations, as it was also reported in wines and cider [14,62]. Specifically, octanoic and decanoic acids have been identified in pomegranate juice $[49,56]$ and wine $[4,11]$. Dodecanoic acid, detected only in M02 and WB06 PABs, derives from pomegranate seeds [63], and it has been found in small amounts in pomegranate juice and in higher concentrations in pomegranate wine and vinegar [57]. Hexadecanoic acid is considered to be the most common saturated fatty acid in plants and has been related to the crystalline structure of plant cell membranes [64]. However, in the present study, it was detected only in SN9 and M02 samples at low concentrations.

\subsubsection{Alcohols}

Alcohols play an important role in the aromatic profile of fermented beverages. However, they are generally considered to have rather unpleasant odors and therefore, it is believed that they contribute more to the intensity of the odor of alcoholic beverages like wines and, therefore, to its quality [60]. 2-Phenylethanol is one of the few fusel alcohols described with a pleasant odor as old rose [60,65], which was detected in all PABs. A reduction in its content at low temperatures $\left(15^{\circ} \mathrm{C}\right)$ was observed, which is in accordance with other studies $[66,67]$. It is considered a key volatile of pomegranate aroma, accounting for almost $40 \%$ of total bound aroma compounds [68]. Another volatile found in almost all PABs was 1-hexanol and its presence is mainly correlated with pasteurized pomegranate products [49,52]. Similarly, 2-ethyl-1-hexanol, a compound with floral attributes, has been found in pomegranate juice [54]. In the present study, it was detected in M02 PAB and at SN9 PAB fermented at $25^{\circ} \mathrm{C}$. The alcohol with the highest concentration in all PABs was 3-methyl-1-butanol, who is responsible for a whiskey, malt, burnt aroma. It has also been found in the stem peels of pomegranates [48]. However, in the present study, its presence is mainly due to the action of yeasts during fermentation. 2,3-butanediol (fruit, onion aroma) is a compound that has previously been reported in commercial pomegranate juices [49] and laboratory-scale pomegranate wines [69] and is considered to be a secondary product 
of pyruvic acid during glyceropyruvic fermentations [26]. In the present study, it was detected in higher concentrations in PAB produced by SN9 yeast. Finally, (Z)-3-hexen-1-ol (grass aroma) has been reported as one of the major volatile compounds of pomegranate seeds [70] and was also found in pomegranate juices [50]. It was detected in all PABs at similar concentrations.

\subsubsection{Terpenes}

Terpenes are compounds that are present in fruit juices naturally, partly in the form of glycosides, which can be hydrolyzed by enzymes or chemically. The processing of juices (e.g., heat treatment) can accelerate these phenomena and therefore alter the terpene profile of these products [71]. Eucalyptol (mint, sweet aroma) is a component that occurs naturally in a number of aromatic plants. As far as pomegranate is concerned, previous studies suggested that it can be found in both fresh pomegranate juice $[50,55]$ and fermented pomegranate beverages [72]. In the present study, it was detected at low concentrations in PABs produced by M02 and SN9 yeasts. $\alpha$-Terpineol, a monoterpene, is a compound found in pomegranate juice [2], contributing to the fruity aroma of products [68]. $\alpha$-Terpineol was detected only in PAB produced by SN9 at $25^{\circ} \mathrm{C}$. It has also been detected in wines [22], however, due to its high perception threshold $\left(0.4 \mathrm{mg} \mathrm{L}^{-1}\right)$, it has very little olfactory impact on pomegranate beverages and wines [73]. Finally, trans-nerolidol that it was detected in all samples fermented at $25^{\circ} \mathrm{C}$, it is a terpene that occurs naturally in the essential oils of many plant and flower types, such as neroli, ginger, hemp, and lemon grass.

\subsubsection{Odor Activity Value of Aroma-Related Compounds}

The odor activity values (OAVs), a marker of the influence on the aroma of individual volatile molecules, for each compound (which is higher than 1 ) is presented in Table 4 . In general, compounds with OAV $>1$ are considered as odor-active compounds. As can be seen, the aroma-related compounds with OAV $>1$ belong mainly to esters and only two in alcohols. These results reveal the possible fruity character of all PABs produced in the present study. As in the case of concentrations, no significant differences were reported between the different temperatures and yeast strains.

Table 4. Aroma compounds quantified in PABs with odor activity value $(\mathrm{OAV})>1$, perception threshold, and aroma descriptions.

\begin{tabular}{|c|c|c|c|c|c|c|c|c|}
\hline \multirow{3}{*}{ Compound } & \multirow{3}{*}{$\begin{array}{l}\text { Threshold } \\
\left(\mathrm{mg} \mathrm{L}^{-1}\right)\end{array}$} & \multirow{3}{*}{$\begin{array}{c}\text { Odor } \\
\text { Description }^{\mathrm{a}}\end{array}$} & \multicolumn{6}{|c|}{ Yeast Strain } \\
\hline & & & \multicolumn{2}{|c|}{ M02 } & \multicolumn{2}{|c|}{ SN9 } & \multicolumn{2}{|c|}{ WB06 } \\
\hline & & & $15^{\circ} \mathrm{C}$ & $25^{\circ} \mathrm{C}$ & $15^{\circ} \mathrm{C}$ & $25^{\circ} \mathrm{C}$ & $15^{\circ} \mathrm{C}$ & $25^{\circ} \mathrm{C}$ \\
\hline ethyl butanoate & $0.4^{\mathrm{a}}$ & $\begin{array}{l}\text { Strawberry, } \\
\text { apple, banana }\end{array}$ & $1.2 \pm 0.2$ & $<1.0$ & $1.6 \pm 1.2$ & $<1.0$ & $1.1 \pm 0.2$ & $1.1 \pm 0.2$ \\
\hline 3-methylbutyl acetate & $0.16^{\mathrm{a}}$ & $\begin{array}{l}\text { Banana, fruity, } \\
\text { sweet }\end{array}$ & $6.6 \pm 0.1$ & $12.5 \pm 5.3$ & $7.3 \pm 1.1$ & $10.2 \pm 2.0$ & $10.0 \pm 3.5$ & $13.9 \pm 0.3$ \\
\hline ethyl hexanoate & $0.08^{\mathrm{a}}$ & $\begin{array}{l}\text { Fruity, green } \\
\text { apple, banana, } \\
\text { brandy, } \\
\text { wine-like }\end{array}$ & $30.2 \pm 0.6$ & $25.8 \pm 13.1$ & $43.1 \pm 11.5$ & $37.5 \pm 5.3$ & $52.5 \pm 7.1$ & $99.9 \pm 79.7$ \\
\hline ethyl octanoate & $0.58^{\mathrm{a}}$ & $\begin{array}{l}\text { Sweet, floral, } \\
\text { fruity, banana, } \\
\text { pear, brandy }\end{array}$ & $6.7 \pm 0.0$ & $5.4 \pm 2.6$ & $10.6 \pm 1.3$ & $7.9 \pm 2.4$ & $23.2 \pm 3.8$ & $15.1 \pm 6.9$ \\
\hline 2-phenylethyl acetate & $1.8^{\mathrm{a}}$ & Flowery & $<1.0$ & $<1.0$ & $<1.0$ & $<1.0$ & $<1.0$ & $1.7 \pm 1.0$ \\
\hline ethyl 9-decanoate & $0.1^{\mathrm{b}}$ & - & $2.5 \pm 0.1$ & $\mathrm{Nd}$ & $3.0 \pm 2.8$ & $\mathrm{Nd}$ & $2.0 \pm 1.4$ & $\mathrm{Nd}$ \\
\hline ethyl decanoate & $0.5^{\mathrm{a}}$ & $\begin{array}{l}\text { Brandy, fruity, } \\
\text { grape }\end{array}$ & $2.2 \pm 0.1$ & $3.8 \pm 2.3$ & $4.1 \pm 0.2$ & $1.1 \pm 0.1$ & $12.3 \pm 6.1$ & $6.6 \pm 2.5$ \\
\hline ethyl dodecanoate & $1.5^{\mathrm{b}}$ & - & $<1.0$ & $1.1 \pm 0.9$ & $<1.0$ & $<1.0$ & $2.1 \pm 0.8$ & $1.8 \pm 0.9$ \\
\hline 3-methyl-1-butanol & $60^{\mathrm{a}}$ & Solvent & $<1.0$ & $<1.0$ & $<1.0$ & $<1.0$ & $<1.0$ & $1.0 \pm 0.5$ \\
\hline 1-hexanol & $1.1^{\mathrm{a}}$ & $\begin{array}{l}\text { Herbaceous, } \\
\text { grass, woody }\end{array}$ & $<1.0$ & $<1.0$ & $\mathrm{Nd}$ & $<1.0$ & $<1.0$ & $3.4 \pm 3.4$ \\
\hline
\end{tabular}

${ }^{\mathrm{a}}$ [74]; ${ }^{\mathrm{b}}$ [75]; $\mathrm{Nd}$, not detected. 


\subsubsection{Chemometrics}

The PCA algorithm, applied to HS-SPME GC/MS data, showed that the fermentation temperature affected significantly volatile composition (Figure 2), since wines produced at $25^{\circ} \mathrm{C}$ were placed at the upper side of the plot and wines produced at $15^{\circ} \mathrm{C}$ were placed at the bottom. PAB produced by WB06 yeast contained compounds in amounts that correlated positively mostly to PC1, whereas M02 yeast resulted in compounds correlated mostly to PC2 for both fermentation temperatures. Consistently, by means of the PC1, it can establish a clear differentiation among the PAB obtained by fermenting pomegranate juice with different microorganisms. More specifically, PABs with M02 and SN9 are placed on the left side of the plot (negative values of PC1), while the PAB produced by WB06 (in both temperatures) are placed on the right side of the plot (positive values of PC1), characterized by the higher amount of alcohols and esters. On the other hand, according to the PC2, a clear distinction was observed between the PAB produced at different fermentation temperatures. The PAB produced at $25^{\circ} \mathrm{C}$, located at the upper side of the plot (positive values of PC2), while those produced at $15^{\circ} \mathrm{C}$, located at the lower side of the plot (negative values of PC2).

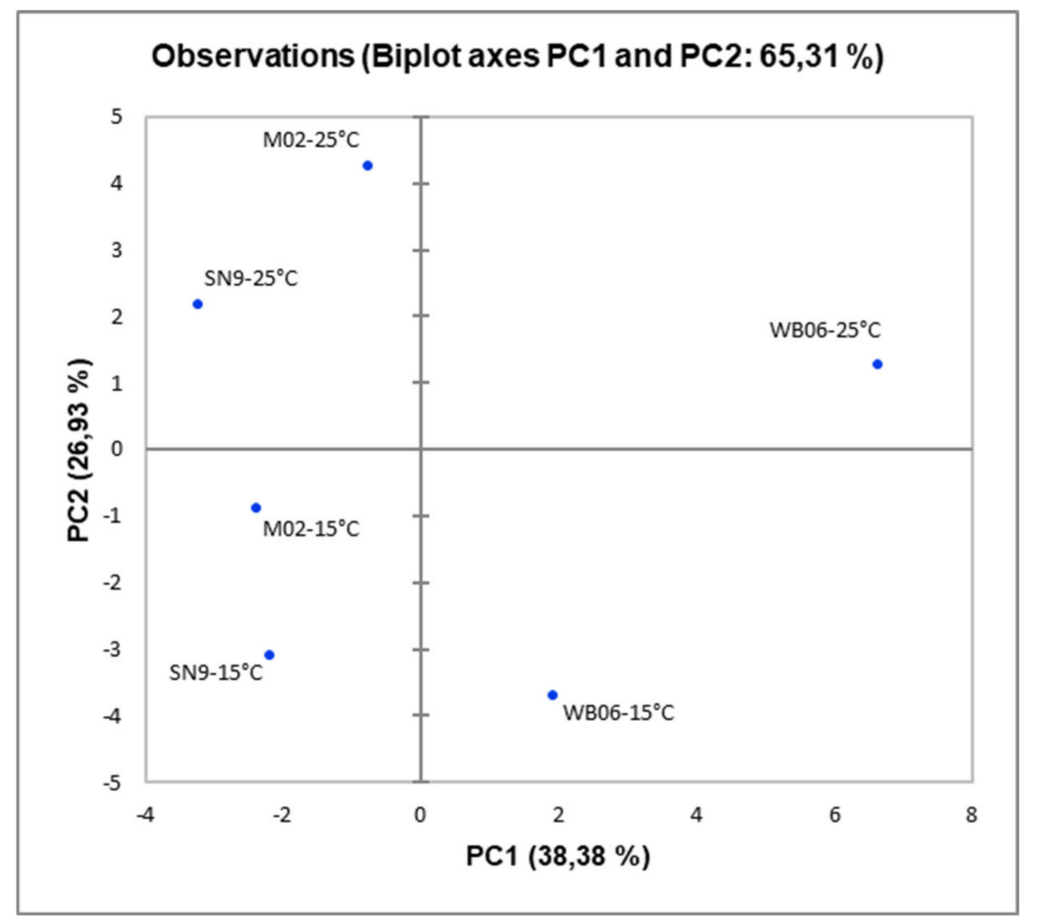

Figure 2. Principal component analysis (PCA) plot of minor volatiles isolated by pomegranate alcoholic beverages fermented at $15^{\circ} \mathrm{C}$ and $25^{\circ} \mathrm{C}$ by different yeasts (M02, SN9, WB06).

\section{Conclusions}

The present study clearly showed that the yeast strain and fermentation temperature are two of the most important factors that affect the characteristics of the final PABs. Different temperatures resulted in similar $\mathrm{pH}$ values and ethanol, glycerol, and acidity content, while significantly affected reducing sugars and antioxidant activities. More specifically, lower temperatures led to higher reducing sugars and lower antioxidant activities and phenolics, probably due to the higher fermentation time. In addition, it affected the volatile profile of final products. In general, all samples presented high free radical-scavenging activities, which is important in such products. Regarding the effect of microorganisms employed for the production of $\mathrm{PAB}$, the selection of the most suitable yeast is tightly related to the nature and characteristics of the material used and the desired characteristics of the final product. In cases of high sugar content and high final alcoholic strength, it appears that SN9 yeast is the most suitable, while, in cases of low initial sugar content, WB06 and M02 yeasts seem better 
candidates. Finally, as far as the aroma profile (analyzed by GC/MS) of PABs is concerned, fermentation temperature is a factor that can cause distinctive profiles for all the yeasts studied, whereas among the yeasts, WB06 is the one that seems to differentiate. These results are considered very promising for the design and development of novel low alcohol products with increased functional characteristics and the appropriate selection of fermentation conditions. However, more studies are needed to evaluate the stability of functional compounds during storage and the possible inclusion of probiotic cells in combination with yeasts.

Author Contributions: Conceptualization, P.K.; methodology, P.K.; validation, E.K., A.N., and P.K.; formal analysis, A.N. and P.K.; investigation, E.K. and A.N.; resources, Y.K. and P.K.; writing-original draft preparation, E.K. and P.K.; writing — review and editing, Y.K. and P.K.; visualization, P.K.; supervision, P.K.; project administration, P.K.; funding acquisition, P.K. All authors have read and agreed to the published version of the manuscript.

Funding: We acknowledge the support for this work by the project "Research Infrastructure on Food Bioprocessing Development and Innovation Exploitation-Food Innovation RI" (MIS 5027222), which is implemented under the Action "Reinforcement of the Research and Innovation Infrastructure", funded by the Operational Program "Competitiveness, Entrepreneurship and Innovation" (NSRF 2014-2020) and co-financed by Greece and the European Union (European Regional Development Fund).

Acknowledgments: The authors would like to thank the personnel of the Laboratory of Food Chemistry and Biochemistry and Laboratory of Dairy Technology of the Department of Food Science and Technology, School of Agriculture, Aristotle University of Thessaloniki, for providing the necessary equipment for certain analyses.

Conflicts of Interest: The authors declare no conflict of interest. The funders had no role in the design of the study; in the collection, analyses, or interpretation of data; in the writing of the manuscript, or in the decision to publish the results.

\section{References}

1. Kandylis, P.; Kokkinomagoulos, E. Food applications and potential health benefits of pomegranate and its derivatives. Foods 2020, 9, 122. [CrossRef]

2. Melgarejo, P.; Calín-Sánchez, Á.; Vázquez-Araújo, L.; Hernández, F.; Martínez, J.J.; Legua, P.; Carbonell-Barrachina, Á.A. Volatile composition of pomegranates from 9 Spanish cultivars using headspace solid phase microextraction. J. Food Sci. 2011, 76, S114-S120. [CrossRef]

3. Raisi, A.; Aroujalian, A.; Kaghazchi, T. Multicomponent pervaporation process for volatile aroma compounds recovery from pomegranate juice. J. Membr. Sci. 2008, 322, 339-348. [CrossRef]

4. Lan, Y.; Wu, J.; Wang, X.; Sun, X.; Hackman, R.M.; Li, Z.; Feng, X. Evaluation of antioxidant capacity and flavor profile change of pomegranate wine during fermentation and aging process. Food Chem. 2017, 232, 777-787. [CrossRef]

5. Jiang, X.; Lu, Y.; Liu, S.Q. Effects of different yeasts on physicochemical and oenological properties of red dragon fruit wine fermented with Saccharomyces cerevisiae, Torulaspora delbrueckii and Lachancea thermotolerans. Microorganisms 2020, 8, 315. [CrossRef]

6. Pereira, A.P.; Mendes-Ferreira, A.; Dias, L.G.; Oliveira, J.M.; Estevinho, L.M.; Mendes-Faia, A. Volatile composition and sensory properties of mead. Microorganisms 2019, 7, 404. [CrossRef]

7. Urbina, K.; Villarreal, P.; Nespolo, R.F.; Salazar, R.; Santander, R.; Cubillos, F.A. Volatile compound screening using HS-SPME-GC/MS on Saccharomyces eubayanus strains under low-temperature pilsner wort fermentation. Microorganisms 2020, 8, 755. [CrossRef]

8. Cousin, F.J.; Le Guellec, R.; Schlusselhuber, M.; Dalmasso, M.; Laplace, J.M.; Cretenet, M. Microorganisms in fermented apple beverages: Current knowledge and future directions. Microorganisms 2017, 5, 39. [CrossRef]

9. Russo, P.; Tufariello, M.; Renna, R.; Tristezza, M.; Taurino, M.; Palombi, L.; Capozzi, V.; Rizzello, C.G.; Grieco, F. New insights into the oenological significance of Candida zemplinina: Impact of selected autochthonous strains on the volatile profile of Apulian wines. Microorganisms 2020, 8, 628. [CrossRef]

10. Gumienna, M.; Szwengiel, A.; Górna, B. Bioactive components of pomegranate fruit and their transformation by fermentation processes. Eur. Food Res. Technol. 2016, 242, 631-640. [CrossRef]

11. Andreu-Sevilla, A.J.; Mena, P.; Martí, N.; Viguera, C.G.; Carbonell-Barrachina, Á.A. Volatile composition and descriptive sensory analysis of pomegranate juice and wine. Food Res. Int. 2013, 54, 246-254. [CrossRef]

12. Lorenzini, M.; Simonato, B.; Slaghenaufi, D.; Ugliano, M.; Zapparoli, G. Assessment of yeasts for apple juice fermentation and production of cider volatile compounds. LWT 2019, 99, 224-230. [CrossRef] 
13. Miller, G.L. Use of dinitrosalicylic acid reagent for determination of reducing sugar. Anal. Chem. 1959, 31, 426-428. [CrossRef]

14. Nikolaou, A.; Galanis, A.; Kanellaki, M.; Tassou, C.; Akrida-Demertzi, K.; Kourkoutas, Y. Assessment of free and immobilized kefir culture in simultaneous alcoholic and malolactic cider fermentations. LWT-Food Sci. Technol. 2017, 76, 67-78. [CrossRef]

15. OIV. International Organisation of Vine and Wine, Compendium of international methods for wine and must analysis (Vol. 1). OIV, Paris, France. 2019. Available online: http://www.oiv.int/public/medias/6619/compend ium-2019-en-vol1.pdf (accessed on 21 August 2020).

16. Papachristoforou, A.; Koutouvela, E.; Menexes, G.; Gardikis, K.; Mourtzinos, I. Photometric analysis of propolis from the island of Samothraki, Greece. The discovery of red propolis. Chem. Biodivers. 2019, 16, e1900146. [CrossRef]

17. Arnous, A.; Makris, D.P.; Kefalas, P. Correlation of pigment and flavanol content with antioxidant properties in selected aged regional wines from Greece. J. Food Comp. Anal. 2002, 15, 655-665. [CrossRef]

18. Lee, J.; Durst, R.W.; Wrolstad, R.E. Determination of total monomeric anthocyanin pigment content of fruit juices, beverages, natural colorants, and wines by the $\mathrm{pH}$ differential method: Collaborative study. J. AOAC Int. 2005, 88, 1269-1278. [CrossRef]

19. Gump, B.H.; Zoecklein, B.W.; Fugelsang, K.C. Prediction of Prefermentation Nutritional Status of Grape Juice. In Food Microbiology Protocols. Methods in Biotechnology; Spencer, J.F.T., de Ragout Spencer, A.L., Eds.; Humana Press: Totowa, NJ, USA, 2001; Volume 14. [CrossRef]

20. Nikolaou, A.; Tsakiris, A.; Kanellaki, M.; Bezirtzoglou, E.; Akrida-Demertzi, K.; Kourkoutas, Y. Wine production using free and immobilized kefir culture on natural supports. Food Chem. 2019, 272, 39-48. [CrossRef]

21. Kandylis, P.; Drouza, C.; Bekatorou, A.; Koutinas, A.A. Scale-up of extremely low temperature fermentations of grape must by wheat supported yeast cells. Biores. Technol. 2010, 101, 7484-7491. [CrossRef]

22. Kandylis, P.; Dimitrellou, D.; Koutinas, A.A. Winemaking by barley supported yeast cells. Food Chem. 2012, 130, 425-431. [CrossRef]

23. Izquierdo-Cañas, P.M.; Vinas, G.; Mena-Morales, A.; Navarro, J.P.; García-Romero, E.; Marchante-Cuevas, L.; Sánchez-Palomo, E. Effect of fermentation temperature on volatile compounds of Petit Verdot red wines from the Spanish region of La Mancha (central-southeastern Spain). Europ. Food Res. Technol. 2020, 246, 1153-1165. [CrossRef]

24. Bagheri, B.; Bauer, F.F.; Cardinali, G.; Setati, M.E. Ecological interactions are a primary driver of population dynamics in wine yeast microbiota during fermentation. Sci. Rep. 2020, 10, 4911. [CrossRef]

25. Fleet, G.H.; Heard, G.M. Yeast-Growth during Fermentation. In Wine, Microbiology and Biotechnology; Fleet, G.H., Ed.; Harwood Academic: Lausanne, Switzerland, 1993.

26. Berenguer, M.; Vegara, S.; Barrajón, E.; Saura, D.; Valero, M.; Martí, N. Physicochemical characterization of pomegranate wines fermented with three different Saccharomyces cerevisiae yeast strains. Food Chem. 2016, 190, 848-855. [CrossRef]

27. Tarantino, A.; Difonzo, G.; Lopriore, G.; Disciglio, G.; Paradiso, V.M.; Gambacorta, G.; Caponio, F. Bioactive compounds and quality evaluation of 'Wonderful' pomegranate fruit and juice as affected by deficit irrigation. J. Sci. Food Agric. 2020. [CrossRef]

28. Rios-Corripio, G.; Guerrero-Beltrán, J.Á. Antioxidant and physicochemical characteristics of unfermented and fermented pomegranate (Punica granatum L.) beverages. J. Food Sci. Technol. 2019, 56, 132-139. [CrossRef]

29. Mena, P.; Gironés-Vilaplana, A.; Martí, N.; García-Viguera, C. Pomegranate varietal wines: Phytochemical composition and quality parameters. Food Chem. 2012, 133, 108-115. [CrossRef]

30. Akalın, A.C.; Bayram, M.; Anlı, R.E. Antioxidant phenolic compounds of pomegranate wines produced by different maceration methods. J. Inst. Brew. 2018, 124, 38-44. [CrossRef]

31. Official Government Gazette of the Hellenic Republic, vol. II; 2161 of 12 June 2018; pp. 23131-23152. "Production and distribution of fermented beverages: Code $\Sigma .0 .22 .06$. Available online: http://www.et.gr/idocs-nph/search /pdfViewerForm.html?args=5C7QrtC22wG3UHk-ZeQumndtvSoClrL8z1uCRhYSV30tiDow6HITE-JInJ4 8_97uHrMts-zFzeyCiBSQOpYnT00MHhcXFRTsJ8r-caBTDshCPvFCUlrHl3-FDnSvNDBKHaRJVdblqUA. (accessed on 21 August 2020). (In Greek).

32. El Kar, C.; Ferchichi, A.; Attia, F.; Bouajila, J. Pomegranate (Punica granatum) juices: Chemical composition, micronutrient cations, and antioxidant capacity. J. Food Sci. 2011, 76, C795-C800. [CrossRef] 
33. Li, X.; Wasila, H.; Liu, L.; Yuan, T.; Gao, Z.; Zhao, B.; Ahmad, I. Physicochemical characteristics, polyphenol compositions and antioxidant potential of pomegranate juices from 10 Chinese cultivars and the environmental factors analysis. Food Chem. 2015, 175, 575-584. [CrossRef]

34. Czyzowska, A.; Pogorzelski, E. Changes to polyphenols in the process of production of must and wines from blackcurrants and cherries. Part, I. Total polyphenols and phenolic acids. Eur. Food Res. Technol. 2002, 214, 148-154. [CrossRef]

35. Ginjom, I.; D'Arcy, B.; Caffin, N.; Gidley, M. Phenolic compound profiles in selected Queensland red wines at all stages of the wine-making process. Food Chem. 2011, 125, 823-834. [CrossRef]

36. Kelebek, H.; Selli, S.; Canbas, A.; Cabaroglu, T. HPLC determination of organic acids, sugars, phenolic compositions and antioxidant capacity of orange juice and orange wine made from a Turkish cv. Kozan. Microchem. J. 2009, 91, 187-192. [CrossRef]

37. Schmitzer, V.; Veberic, R.; Slatnar, A.; Stampar, F. Elderberry (Sambucus nigra L.) wine: A product rich in health promoting compounds. J. Agric. Food Chem. 2010, 58, 10143-10146. [CrossRef]

38. Pérez-Gregorio, M.R.; Regueiro, J.; Alonso-González, E.; Pastrana-Castro, L.M.; Simal-Gándara, J. Influence of alcoholic fermentation process on antioxidant activity and phenolic levels from mulberries (Morus nigra L.). LWT - Food Sci. Technol. 2011, 44, 1793-1801. [CrossRef]

39. Caridi, A.; Cufari, A.; Lovino, R.; Palumbo, R.; Tedesco, I. Influence of yeast on polyphenol composition of wine. Food Technol. Biotechnol. 2004, 42, 37-40.

40. Brandolini, V.; Fiore, C.; Maietti, A.; Tedeschi, P.; Romano, P. Influence of Saccharomyces cerevisiae strains on wine total antioxidant capacity evaluated by photochemiluminescence. World J. Microbiol Biotechnol. 2007, 23, 581-586. [CrossRef]

41. Carew, A.L.; Smith, P.; Close, D.C.; Curtin, C.; Dambergs, R.G. Yeast effects on Pinot noir wine phenolics, color, and tannin composition. J. Agric. Food Chem. 2013, 61, 9892-9898. [CrossRef]

42. Caridi, A.; Sidari, R.; Giuffrè, A.M.; Pellicanò, T.M.; Sicari, V.; Zappia, C.; Poiana, M. Test of four generations of Saccharomyces cerevisiae concerning their effect on antioxidant phenolic compounds in wine. Eur. Food Res. Technol. 2017, 243, 1287-1294. [CrossRef]

43. Ivanova, V.; Dörnyei, Á.; Márk, L.; Vojnoski, B.; Stafilov, T.; Stefova, M.; Kilár, F. Polyphenolic content of Vranec wines produced by different vinification conditions. Food Chem. 2011, 124, 316-325. [CrossRef]

44. Ivanova, V.; Vojnoski, B.; Stefova, M. Effect of winemaking treatment and wine aging on phenolic content in Vranec wines. J. Food Sci. Technol. 2012, 49, 161-172. [CrossRef]

45. Alighourchi, H.; Barzegar, M. Some physicochemical characteristics and degradation kinetic of anthocyanin of reconstituted pomegranate juice during storage. J. Food Eng. 2009, 90, 179-185. [CrossRef]

46. Mateus, N.; de Freitas, V. Evolution and stability of anthocyanin-derived pigments during port wine aging. J. Agric. Food Chem. 2001, 49, 5217-5222. [CrossRef]

47. Czyżowska, A.; Pogorzelski, E. Changes to polyphenols in the process of production of must and wines from blackcurrants and cherries. Part II. Anthocyanins and flavanols. Eur. Food Res. Technol. 2004, 218, 355-359. [CrossRef]

48. Jung, J.S. Analysis of volatile compounds in the root peel, stem peel, and fruit peel of pomegranate (Punica granatum) by TD GC/MS. Int. J. Biosci. Biotechnol. 2014, 6, 169-181. [CrossRef]

49. Beaulieu, J.C.; Stein-Chisholm, R.E. HS-GC-MS volatile compounds recovered in freshly pressed 'Wonderful' cultivar and commercial pomegranate juices. Food Chem. 2016, 190, 643-656. [CrossRef]

50. Beaulieu, J.C.; Obando-Ulloa, J.M. Not-from-concentrate pilot plant 'Wonderful' cultivar pomegranate juice changes: Volatiles. Food Chem. 2017, 229, 553-564. [CrossRef]

51. Styger, G.; Prior, B.; Bauer, F.F. Wine flavor and aroma. J. Ind. Microbiol. Biotechnol. 2011, 38, 1145. [CrossRef]

52. Vázquez-Araújo, L.; Chambers IV, E.; Adhikari, K.; Carbonell-Barrachina, Á.A. Sensory and physicochemical characterization of juices made with pomegranate and blueberries, blackberries, or raspberries. J. Food Sci. 2010, 75, S398-S404. [CrossRef]

53. Allam, H. Impact of processing on flavor volatiles and physicochemical properties of pomegranate juice. Suez Canal Univ. J. Food Sci. 2016, 3, 67-74. [CrossRef]

54. Mayuoni-Kirshinbaum, L.; Porat, R. The flavor of pomegranate fruit: A review. J. Sci. Food Agric. 2014, 94, 21-27. [CrossRef] 
55. Beaulieu, J.; Grimm, C.; Lloyd, S.; Stein, R. Characterizing endogenous and oxidative low molecular weight flavor/aroma compounds in fresh squeezed/blended pomegranate juice. In Proceedings of the Annual Meeting Horticultural Society, 31 July-5 August 2010; Palm Desert, CA, USA.

56. Caleb, O.J.; Opara, U.L.; Mahajan, P.V.; Manley, M.; Mokwena, L.; Tredoux, A.G. Effect of modified atmosphere packaging and storage temperature on volatile composition and postharvest life of minimally-processed pomegranate arils (cvs. 'Acco' and 'Herskawitz'). Postharvest Biol. Technol. 2013, 79, 54-61. [CrossRef]

57. Kharchoufi, S.; Gomez, J.; Lasanta, C.; Castro, R.; Sainz, F.; Hamdi, M. Benchmarking laboratory-scale pomegranate vinegar against commercial wine vinegars: Antioxidant activity and chemical composition. J. Sci. Food Agric. 2018, 98, 4749-4758. [CrossRef]

58. Rodríguez-Lerma, G.K.; Gutiérrez-Moreno, K.; Cárdenas-Manríquez, M.; Botello-Álvarez, E.; Jiménez-Islas, H.; Rico-Martínez, R.; Navarrete-Bolaños, J.L. Microbial ecology studies of spontaneous fermentation: Starter culture selection for prickly pear wine production. J. Food Sci. 2011, 76, M346-M352. [CrossRef]

59. Whiting, G.C. Organic acid metabolism of yeasts during fermentation of alcoholic beverages-A review. J. Inst. Brew. 1976, 82, 84-92. [CrossRef]

60. Etievant, X.P. Wine. In Volatile compounds in foods and beverages, 1st ed.; Maarse, H., Ed.; Marcel Dekker: New York, NY, USA, 1991; pp. 483-533. [CrossRef]

61. Jackson, R.S. Wine Science: Principles and Applications, 1st ed.; Academic Press: San Diego, CA, USA, 1994.

62. Kandylis, P.; Mantzari, A.; Koutinas, A.A.; Kookos, I.K. Modelling of low temperature wine-making, using immobilized cells. Food Chem. 2012, 133, 1341-1348. [CrossRef]

63. Melgarejo, P.; Salazar, D.M.; Amoros, A.; Artes, F. Total lipids content and fatty acid composition of seed oils from six pomegranate cultivars. J. Sci. Food Agric. 1995, 69, 253-256. [CrossRef]

64. Zhukov, A.V. Palmitic acid and its role in the structure and functions of plant cell membranes. Russ. J. Plant. Physiol. 2015, 62, 706-713. [CrossRef]

65. Tsakiris, A.; Bekatorou, A.; Psarianos, C.; Koutinas, A.A.; Marchant, R.; Banat, I.M. Immobilization of yeast on dried raisin berries for use in dry white wine-making. Food Chem. 2004, 87, 11-15. [CrossRef]

66. Kandylis, P.; Koutinas, A.A. Extremely low temperature fermentations of grape must by potato-supported yeast, strain AXAZ-1. A contribution is performed for catalysis of alcoholic fermentation. J. Agric. Food Chem. 2008, 56, 3317-3327. [CrossRef]

67. Mallouchos, A.; Komaitis, M.; Koutinas, A.; Kanellaki, M. Investigation of volatiles evolution during the alcoholic fermentation of grape must using free and immobilized cells with the help of solid phase microextraction (SPME) headspace sampling. J. Agric. Food Chem. 2002, 50, 3840-3848. [CrossRef]

68. Tripathi, J.; Chatterjee, S.; Gamre, S.; Chattopadhyay, S.; Variyar, P.S.; Sharma, A. Analysis of free and bound aroma compounds of pomegranate (Punica granatum L.). LWT-Food Sci. Technol. 2014, 59, 461-466. [CrossRef]

69. Dushing, P.M. Production of wine from mahua flower (Madhuca Indica L.) extract and pomegranate (Punica granatum L.) fruit juice. Master's Thesis, Vasantrao Naik Marathwada Krishi Vidyapeeth University, Parbhani, Maharashtra, India, 2019.

70. Güler, Z.; Gül, E. Volatile organic compounds in the aril juices and seeds from selected five pomegranate (Punica granatum L.) cultivars. Int. J. Food Prop. 2017, 20, 281-293. [CrossRef]

71. Nuncio-Jáuregui, N.; Calín-Sánchez, Á.; Vázquez-Araújo, L.; Pérez-López, A.J.; Frutos-Fernández, M.J.; Carbonell-Barrachina, Á.A. Processing pomegranates for juice and impact on bioactive components. In Processing and Impact on Active Components in Food; Preedy, V., Ed.; Academic Press: Cambridge, MA, USA, 2015; pp. 629-636.

72. Mantzourani, I.; Kazakos, S.; Terpou, A.; Alexopoulos, A.; Bezirtzoglou, E.; Bekatorou, A.; Plessas, S. Potential of the probiotic Lactobacillus plantarum ATCC 14917 strain to produce functional fermented pomegranate juice. Foods 2019, 8, 4. [CrossRef]

73. Ribérau-Gayon, P.; Glories, Y.; Maujean, A.; Dubourdieu, D. The chemistry of wine stabilization and treatments. In Handbook of enology; John Wiley \& Sons Ltd.: Chichester, UK, 2000; pp. 41-54. 
74. Peinado, R.A.; Moreno, J.; Bueno, J.E.; Moreno, J.A.; Mauricio, J.C. Comparative study of aromatic compounds in two young white wines subjected to pre-fermentative cryomaceration. Food Chem. 2004, 84, 585-590. [CrossRef]

75. Tao, Y.; Zhang, L. Intensity prediction of typical aroma characters of cabernet sauvignon wine in Changli County (China). LWT-Food Sci. Technol. 2010, 43, 1550-1556. [CrossRef]

Publisher's Note: MDPI stays neutral with regard to jurisdictional claims in published maps and institutional affiliations.

(C) 2020 by the authors. Licensee MDPI, Basel, Switzerland. This article is an open access article distributed under the terms and conditions of the Creative Commons Attribution (CC BY) license (http://creativecommons.org/licenses/by/4.0/). 